\title{
A Study on the Application of BIM in Civil Engineering Professional Practice
}

\author{
Z.Y. ZHANG \& K.M. LIU \\ School of Human Settlement and Civil Engineering, Xi'an Jiaotong University, Xi 'an, Shaanxi, China
}

\begin{abstract}
The Civil engineering professional practice is an important teaching link to cultivate students' practical ability. For a variety of reasons, its teaching effect is not general good enough. This paper discusses the possibility of integrating BIM with civil engineering professional practice and shows that the teaching effect of the civil engineering professional practice will be dramatically enhanced by the application of BIM. KEYWORD: BIM; Civil Engineering; Professional Practice; Teaching Effect
\end{abstract}

\section{INTRODUCTION}

Civil engineering professional practice is an important teaching link for personnel training. The practice bases for the professional practice are at building construction sites in general. Many construction units do not want the interns to access the construction layer for safety. Although the interns' safety problem attracts a certain attention, it still causes the problem that the interns cannot be objectively integrated into the construction practice in construction project. Additionally it is not effective for the interns to establish a system of practical cognition for each link in the construction process. In the end it lowers the level of interns' enthusiasm and participation and causes the poor effect of the practice teaching.(Lei Jinshenget al. 2010)

With the rapid development of the construction industry, BIM (Building Information Modeling) technology is widely used in the modern civil engineering practice. In details, BIM can integrate all kinds of information in construction, which contains the expression of all the details in the project through the simulation for the building. Moreover, it has been used as a visualdesign and construction method, not only systematically expressing the whole process of construction project, but also reducing the risk and improving the interns' safety. In sum, BIM has a great application value in virtual construction, the management the life cycle of building and other aspects and it is an inevitable trend in the development of the construction industry.(Volk et al. 2014)

\section{THE POSSIBILITY OF INTEGRATING BIM WITH CIVIL ENGINEERING PROFESSIONAL PRACTICE}

\subsection{BIM technology and related software are gradually integrated into the curriculum of colleges and universities}

Since Building Information Modeling is put forward by Tolman at 1999, BIM is recognized by the world gradually. (ZengFanhonget al. 2014) After entering the 21 st century, there has been a growing level of interests in applying BIM in construction industry and BIM has become the trend for the construction industry informationtization.(Volk et al. 2014)

With the popularity of BIM, many colleges and universities are also involved in the BIM research and teaching at home and abroad. According to a survey in the United States, 70\% of colleges and universities have set BIM courses; for other colleges and universities, $88 \%$ of them have plans to set BIM courses. Some of the successful colleges and universities are Pennsylvania State University and California Institute of Technology etc. The specific data analysis is show in Figure 1.(Pavelko 2010)

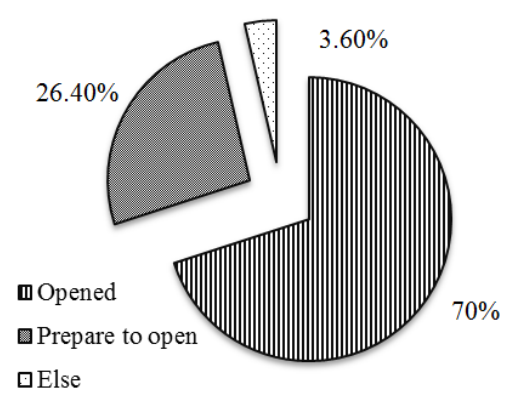

Figure 1. BIM education in American universities (Pavelko 2010) 
In China, the National Association of Construction Education has held "Thsware Cup" National BIM Contest for College Students for 5 times since 2010.At the same time, BIM courses have gradually been set into the college curriculum in comprehensive colleges such as Tsinghua University, Tongji University, Harbin Institute of Technology and construction vocational colleges such as Sichuan Construction Vocational College, Jiangsu Construction Vocational College and Heilongjiang Construction Vocational College. (CengFanyong \& TaoGonglin, 2014, p.)

\subsection{BIM helps interns improve the understanding of construction process}

If the interns intend to apply BIM software for construction simulation during the internship to complete the construction simulation, it is necessary to do a detailed and in-depth research for the construction project. The interns may find more problems in the construction practice when they apply BIM software for construction simulation. Therefore, they are expected to invest more time and effort to do in-depth research and study to solve those problems. During this process, the enthusiasm of the interns' self-regulate learning and the effect of the practical teaching will be greatly enhanced.

At the same time, there is a one to one correspondence between BIM and a specific construction project.BIM varies from project to project so that the plagiarism can be avoided in the internship reports and summaries and the interns' results will be more explicitly reflected in the professional practice.

BIM not only can be applied in construction stage of the construction process, but also involves the whole life cycle of building. Interns can be familiar with the construction process of the construction project as well as understand the entire construction process and the whole life cycle of building through BIM.BIM not only resolve the contradiction between the long construction period and the short internship period, but also can make the interns get more professional knowledge in the short internship period.

\subsection{BIM can strengthen the exchanges between the interns and the employers and improve interns, motivation}

Applying BIM software for construction simulation can promote the interns to communicate with the civil engineer technician in the internship units so that the employers will offer more guidance and help for interns. Besides, the employers can find construction problems in time the under the forming process of BIM.

The interns can be involved in every process of the professional practice by strengthen the exchanges between the interns and the employers, which inevitably means that the interns' motivations and the practice teaching effect gets improved.

\subsection{BIM can improve the presence of the practice achievements}

When the employers encounter technical problems in the practice process of applying BIM, the interns can apply the BIM software for construction simulation to simulate a solution. The internship process which is by applying BIM can improve interns' motivation, and the BIM forms can provide a more vivid reflection of the practice achievement of interns because the BIM forms not only require the establishment of the three-dimensional model of the building but also the animation shows, which will provide more information than the traditional internship report. Also, BIM will promote the interns' ability and confidence in practice and will increase their employment opportunities in the future.

\section{SUMMARY}

Due to the weakness of traditional civil engineering professional practice schema, BIM is the inevitable developing trend of the professional practice education. Applying BIM in the professional practice can helps interns improve the understanding of construction process, strengthen the exchanges between the interns and the employers and improve interns' motivation and improve the presence of the practice achievements.BIM will enhance the teaching effect of civil engineering professional practice finally.

\section{REFERENCES}

[1] Lei, Jinsheng. \& Zhang, Jingsui. \& Zhang, Guodong. \& Yang, Jun. 2014. A Study of Flexible Manage Mechanism and Three-dimensional Dynamic Model of Practice Teaching in Civil Engineering Specialty. Journal of Architectural Education in Institutions of Higher Learning: 7-9.

[2] Liu, Hongyong. \& He, Weitao. \& Huang, Qiushuang. 2013. The Exploration Path to Teaching Practice of BIM in Normal Colleges and Universities. Journal of Information Technology in Civil Engineering and Architeture: 98-101.

[3] Pavelko,C. Building Information Modeling in Today's University Undergraduate Curriculum.Arizona State University, 2010.

[4] Volk, R., Stengel, J., and Schultmann, F. (2014). "Building Information Modeling (BIM) for existing buildings Literature review and future needs." Automation in Construction, 38(0), 109-127.

[5] Zeng, Fanhong. \& Tao, Honglin. 2014. The exploration Path on training BIM Technical Talents in Construction Vocational Colleges. Journal of Liaoning Higher Vocational:7-9 